\title{
Extraneural metastases in medulloblastoma
}

\author{
Valéria Marques Figueira Muoio', Sueli Oba Shinjo², \\ Hamilton Matushita ${ }^{3}$, Sérgio Rosemberg4, \\ Manoel Jacobsen Teixeira ${ }^{5}$, Suely Kazue Nagahashi Marie ${ }^{6}$
}

\begin{abstract}
Medulloblastoma is the most common childhood malignant tumor of central nervous system, but it may also occur in adults. It presents high invasive growth with spreading of tumor cells into the leptomeningeal space along the neuroaxis early in the course of the disease. Extraneural metastases are rare but frequently lethal, occurring only in 1 to $5 \%$ of patients, and are related, in the most of cases, to the presence of ventriculoperitoneal shunt. Here we characterize the clinical profile of five cases of medulloblastoma with systemic spreading of tumor cells, also comparing them to cases already described in the literature.
\end{abstract}

Key words: medulloblastoma, metastasis, extraneural.

\section{Mestástases extraneurais em moduloblastoma}

\section{RESUMO}

O meduloblastoma é o tumor maligno mais frequente do sistema nervoso central na infância, mas também pode ocorrer em adultos. Ele apresenta crescimento altamente invasivo com disseminação de células tumorais ao longo do neuroeixo precocemente no curso da doença. Metástases extraneurais são raras mas frequentemente letais, ocorrendo apenas em 1 a $5 \%$ dos pacientes, e estão relacionadas, na maioria dos casos, a presença de derivação ventriculperitoneal. Neste artigo, apresentamos o perfil de cinco casos de meduloblastoma com disseminção sistêmica das células tumorais, comparando-os com os casos já descritos na literatura.

Palavras-chave: medulloblastoma, metastases, extraneural.

Medulloblastoma is the most frequent malignant tumor of the central nervous system (CNS) in children, but it can also occur in adults. It is usually restricted to the CNS, and its metastases often occur along the neuroaxis.The systemic (extraneural) medulloblastoma metastases are rare, severe and related with a very poor prognosis. We report five patients with extraneural metastases of medulloblastoma, followed in our hospital during the period from 1996 to 2009.

\section{METHOD}

Along the last 13 years, we have followed-up five patients (5\%) with systemic metastasis among 96 patients with medulloblastoma. There were 2 children and 3 adults (ages between 2 and 30). Three of them presented the tumor located at cerebellar vermis, and two at cerebellar hemisphere. The histological subtypes were classic in 3 cases, and desmoplastic in 2 cases. The children had bone marrow metastasis only, while the adults had several
Valéria Marques Figueira Muoio Rua Maestro Cardim 808 01323-001 São Paulo SP - Brasil

E-mail: valeria.muoio@gmail.com

Received 18 March 2010

Received in final form 27 September 2010 Accepted 5 October 2010
${ }^{1} \mathrm{MD}$, PhD Neurology Department, Medicine School, University of São Paulo (FMUSP), São Paulo SP, Brazil; ${ }^{2} \mathrm{PhD}$ Researcher, Neurology Department, FMUSP; ${ }^{3} \mathrm{MD}, \mathrm{PhD}$ Neurosurgeon, Neurology Department, FMUSP; ${ }^{4} \mathrm{MD}, \mathrm{PhD}$ Pathologist, Pathology Department, FMUSP; ${ }^{5} \mathrm{MD}$, PhD Neurosurgery Department, FMUSP, Chairman; ${ }^{6} \mathrm{MD}$, PhD Neurology Department, FMUSP. 
Table 1. Clinical findings of the five patients presenting extraneural metastases of medulloblastoma.

\begin{tabular}{|c|c|c|c|c|c|}
\hline Case & 1 & 2 & 3 & 4 & 5 \\
\hline Age at neurosurgery & 2 & 30 & 29 & 30 & 7 \\
\hline Gender & M & $\mathrm{F}$ & $\mathrm{F}$ & M & M \\
\hline Tumor topography & vermis & hemispheric & vermian & hemispheric & vermis \\
\hline Hydrocephalus/shunt & $+/+$ & $+/+$ & $+/+$ & $-/-$ & $+/+$ \\
\hline Morphological diagnosis & classic & desmoplastic & desmoplastic & classic & classic \\
\hline Overall survival (months) & 12 & 18 & 22 & 45 & 9 \\
\hline $\begin{array}{l}\text { Time to recurrence or } \\
\text { metastasis (months) }\end{array}$ & 8 & 12 & 18 & 38 & 6 \\
\hline Site of metastasis & bone marrow & $\begin{array}{l}\text { abdomen } \\
\text { and pelvis }\end{array}$ & $\begin{array}{l}\text { peritoneum, } \\
\text { lungs, bones and } \\
\text { lymph nodes }\end{array}$ & $\begin{array}{l}\text { bone marrow, } \\
\text { bones, lymph } \\
\text { nodes }\end{array}$ & bone marrow \\
\hline Cause of death & $\begin{array}{l}\text { severe anemia } \\
\text { and sepsis }\end{array}$ & renal failure & $\begin{array}{l}\text { ventilatory } \\
\text { failure }\end{array}$ & $\begin{array}{l}\text { severe anemia } \\
\text { and sepsis }\end{array}$ & sepsis \\
\hline
\end{tabular}

organs compromised. Interestingly, only one out five patients did not present hydrocephalus, consequently had no demand of ventriculoperitoneal (VP) shunt, and presented the longer interval between surgery and detection of extraneural metastasis (38 months). The adult patients that have developed abdominal metastasis had previously undergone a VP shunt procedure. However, the children did not have abdominal metastasis despite the VP shunt. No relation between age, histological types and target organs was established due to the restricted number of studied cases. Concerning the natural history of the disease, the time between the initial symptoms of the CNS disease and the onset of the metastasis ranged from 6 to 38 months, and all of them received a standard treatment: surgical tumor resection and adjuvant treatment. They have in common the short survival after the metastases were identified, despite of proper treatment.

The details of the clinical profile of these five patients are presented on Table 1.

\section{DISCUSSION}

The medulloblastoma metastases usually occur along the spinal cord, following the cerebrospinal outflow, or along the ventricular system, where it can implant, soak and grow ${ }^{1}$. Extraneural metastases, however, are rare ${ }^{2-4}$, and there are about 119 patients with extraneural medulloblastoma metastases previously described in the literature ${ }^{5}$. The peculiarities of the brain blood barrier and the differences between the CNS and the systemic environment may explain the rarity of this occurrence. The blood brain barrier represents an obstacle for the tumoral clones, making difficult their mobility. The systemic environment, in its turn, may not offer the ideal conditions to a medulloblastoma clone to implant, soak and grow. Even with this scenario, medulloblastoma, among all pediatric CNS tumors, has the greatest potential for extraneural spread ${ }^{6}$. There are few theories to explain this phenomenon. Fiorilli et al. ${ }^{7}$ in 2008 described some medulloblastoma molecular features that can help our understanding in this matter. He described increased expression levels of integrins and tenascins in the medulloblatoma cells. Integrin mediates adhesion of medulloblastoma cells associated to tenascin, which is expressed in the extracellular matrix, and activate pathways associated with cell survival and proliferation. This interaction may be able to guarantee proliferation and adhesion of tumor cells at remote sites, as in neuroaxis, and even out of CNS. In the following year, Osawa et al. ${ }^{8}$ described that in addition to other cytoskeletal proteins, ezrin plays an important role in medulloblastoma adhesion, migration, and invasion; reassuring the idea of the great metastatic potential of medulloblastoma .

Previous studies ${ }^{9,10}$ report that the systemic metastases can occur from 3 to $5 \%$ of the medulloblastoma population, but there is a lack of reports concerning some aspects of the disease, as histological type, tumor topography and survival rate. These blanks in the details of patients with systemic metastasis of medulloblastoma leave incomplete the clinical profile or the natural history of this severe condition. The present report of five cases and the review of previously reported cases have the aim to try to fulfill this gap. Summarized characteristics of the previously reported cases are presented on Table 2 .

The majority of the previous reports described fewer patients, with the exception of the publications of Eberhart (with emphasis in pathological aspects), Campbell (including gliomas in the casuistic) and Mazloom, who performed a review of the literature and established prognostic factors to patients with extraneural metastasis, as CNS recurrence and radiotherapy. However, no 
Table 2. Previous reported cases of extraneural metastasis of medulloblastoma.

\begin{tabular}{|c|c|c|c|c|c|c|c|c|}
\hline Author & Year & NC & G & Subtype & $\begin{array}{c}\text { Time between diagnosis } \\
\text { and metastasis }\end{array}$ & Site of metastasis & Shunt & $\begin{array}{l}\text { Overall } \\
\text { survival }\end{array}$ \\
\hline Hoffman ${ }^{11}$ & 1976 & 4 & $B$ & na & 15 & peritoneum & + & 21 \\
\hline Duffner ${ }^{12}$ & 1981 & 4 & B & na & na & $b, b m, p$ & + & na \\
\hline Kleinman² & 1981 & 2 & B & na & $9-13$ & $p, b$, lu, ly & - & 23 \\
\hline McComb ${ }^{13}$ & 1981 & 6 & B & na & $0-10$ & $\mathrm{~b}, \mathrm{bm}, \mathrm{lu}$, neck & + & na \\
\hline Lowery $^{14}$ & 1982 & 6 & B & na & 12 & $b, b m$ & na & na \\
\hline Vanneste $^{15}$ & 1983 & 1 & $\mathrm{~F}$ & na & 12 & orbit & na & na \\
\hline Campbel $^{3}$ & 1984 & 15 & $B$ & na & na & b, bm, p, li, lu & + & 16 \\
\hline Spencer ${ }^{16}$ & 1984 & 4 & B & na & na & $\mathrm{bm}$ & na & na \\
\hline Mahoney ${ }^{17}$ & 1986 & 1 & M & na & 19 & $b, b m$ & na & 60 \\
\hline $\operatorname{Vieco}^{18}$ & 1989 & 5 & $\mathrm{~B}$ & na & na & $b$ & na & na \\
\hline Krouwer ${ }^{19}$ & 1991 & 1 & M & desmoplastic & na & pancreas & + & na \\
\hline Olson ${ }^{20}$ & 1991 & 1 & M & na & 6 & bones & na & na \\
\hline Jamjoom ${ }^{21}$ & 1993 & 1 & M & na & na & scrotum & + & na \\
\hline Eberhart ${ }^{22}$ & 2003 & 23 & B & na & $0-138$ & b, bm, ly, lu & na & $0-138$ \\
\hline Yoshimura ${ }^{23}$ & 2005 & 1 & M & na & 10 & mandibular bone & na & 30 \\
\hline $\operatorname{Varan}^{6}$ & 2006 & 6 & $B$ & na & 17 & $\mathrm{li}, \mathrm{lu}, \mathrm{b}, \mathrm{bm}$ & + & 10 \\
\hline Wendland ${ }^{24}$ & 2006 & 1 & $\mathrm{~F}$ & na & 6 & $b$, ly, st & na & 20 \\
\hline Srinivas ${ }^{25}$ & 2007 & 1 & M & desmoplastic & 1 & mandibular bone & na & 60 \\
\hline Mazloom ${ }^{5 *}$ & 2010 & 119 & B & na & 10 & b, bm, lu, li, ly & + & 26 \\
\hline
\end{tabular}

NC: number of cases; G: gender; M: male; F: female; B: gender not discriminated; b: bones; bm: bone marrow; lu: lungs; li: liver; ly: lymph nodes; st: soft tissue; na: information not available; * ${ }^{*}$ review(meta-analysis).

predictive factors to extraneural metastases development were yet identified. Presence of VP shunt has been described as a risk factor to this condition by others ${ }^{11,21,26,27}$, especially to bone marrow ${ }^{16}$, bones ${ }^{28}$, abdomen ${ }^{19,22,26,27}$, and lymph nodes ${ }^{13,29,30}$. Extraneural metastasis in medulloblastoma is usually considered as a late-stage complication in the natural history of the disease, however, in our series two patients presented extraneural metastasis within one year from the surgical resection of the primary tumor.

A meta-analysis of the data concerning extraneural metastasis of medulloblastoma, including our findings, allow us to conclude that: [1] the most common sites of metastasis are bone marrow and bones, followed by peritoneum, lungs and liver, [2] systemic metastasis of medulloblastoma is a rare condition, [3] metastasis aggravates the natural history of the primary condition, and [4] it is a factor that worsen the prognosis.

\section{REFERENCES}

1. Hsieh PC, Wu CT, Lin KL, et al. The clinical experience of medulloblastoma treatment and the significance of time sequence for development of leptomeningeal metastasis. Childs Nerv Syst 2008;24:1463-1467.

2. Kleinman GM, Hochberg FH, Richardson EP Jr. Systemic metastases from medulloblastoma: report of two cases and review of the literature. Cancer 1981;48:2296-2309.

3. Campbell AN, Chan HS, Becker LE, et al. Extracranial metastases in child- hood primary intracranial tumors: a report of 21 cases and review of the literature. Cancer 1984;53:974-981.

4. Mattos JP, Bonilha L, Ferreira D, Borges W, Fernandes YB, Borges G. Multiple systemic metastases of posterior fossa - primitive neuroectodermal tumor (PF-PNET) in adult: case report. Arq Neuropsiquiatr 2003;61:100-103.

5. Mazloom A, Zangeneh AH, Paulino AC. Prognostic factors after extraneural metastasis of medulloblastoma. Int J Radiat Oncol Biol Phys 2010;78:72-78.

6. Varan A, Sari N, Akalan N, et al. Extraneural metastasis in intracranial tumors in children: the experience of a single Center. J Neurooncol 2006; 79:187-190

7. Fiorilli P, Partridge D, Staniszewska I, et al. Integrins mediate adhesion of medulloblastoma cells to tenascin and activate pathways associated with survival and proliferation. Lab Invest 2008:88:1143-1156.

8. Osawa H, Smith CA, Ra YS, Kongkham P, Rutka JT. The role of the membrane cytoskeleton cross-linker ezrin in medulloblastoma cells. Neuro Oncol 2009;11:381-393.

9. Huber A, Bohl J, Gutjahr P. Treatment of an extraneural metastasized medulloblastoma. Kinderklinik, Johannes Gutenberg-Universität Mainz. Skeletal Radiol 1989;18:445-449.

10. Kochbati L, Bouaouina N, Hentati D, et al. Medulloblastoma with extracentral nervous system metastases: clinical presentation and risk factors. Cancer Radiother 2006;10:107-111.

11. Hoffman HJ, Hendrick EB, Humphreys RP. Metastasis via ventriculoperitoneal shunt in patients with medulloblastoma. J Neurosurg 1976;44: 562-566.

12. Duffner PK, Cohen ME. Extraneural metastases in childhood brain tumors. Ann Neurol 1981;10:261-265.

13. McComb JG, Davis RL, Isaacs H Jr. Extraneural metastatic medulloblastoma during childhood. Neurosurgery 1981;9:548-551.

14. Lowery GS, Kimball JC, Patterson RB, Raben M. Extraneural metastases from cerebellar medulloblastoma. Am J Pediatr Hematol Oncol 1982;4:259-262.

15. Vanneste JA. Subacute bilateral malignant exophthalmos due to orbital medulloblastoma metastases. Arch Neurol 1983;40:441-443. 
16. Spencer CD, Weiss RB, Van Eys J, et al. Medulloblastoma metastatic to the marrow: report of four cases and review of the literature. J Neurooncol 1984;2:223-235

17. Mahoney DH Jr, Steuber CP, Sandbach JF, Fernbach DJ. Extraneural metastases from medulloblastoma: long-term survival after sequentially sched uled chemotherapy and radiotherapy. Med Pediatr Oncol 1986;14:329-331.

18. Vieco PT, Azouz EM, Hoeffel JC. Metastases to bone in medulloblastoma: a report of five cases. Skeletal Radiol 1989;18:445-449.

19. Krouwer HG, Vollmerhausen J, White J, et al. Desmoplastic medulloblastoma metastatic to the pancreas: case report. Neurosurgery 1991;29: 612-616.

20. Olson EM, Tien RD, Chamberlain MC. Osseous metastasis in medulloblastoma: MRI findings in an unusual case. Klin Padiatr Clin Imaging 1991;15: 286-289.

21. Jamjoom ZA, Jamjoom AB, Sulaiman AH, Naim-Ur-Rahman, al Rabiaa A Systemic metastasis of medulloblastoma through ventriculoperitoneal shunt: report of a case and critical analysis of the literature. Surg Neurol 1993:40:403-410.

22. Eberhart CG, Cohen KJ, Tihan T, Goldthwaite PT, Burger PC. Medulloblastomas with systemic metastases: evaluation of tumor histopathology and clinical behavior in 23 patients. Pediatr Hematol Oncol 2003;25: 198-203.

23. Yoshimura J, Nishiyama K, Takahashi H, Mori H, Tanaka R, Umezu H. Medulloblastoma with mandibular metastasis after complete remission of the central nervous system lesions. No to Shinkei 2005;57:37-40.

24. Wendland MM, Shrieve DC, Watson GA, Chin SS, Blumenthal DT. Extraneural metastatic medulloblastoma in an adult. J Neurooncol 2006;78:191-196.

25. Srinivas C, Gupta T, Rajasekharan P, Munshi A. Bilateral mandibular metastases in medulloblastoma. J Clin Neurosci 2009;16:325-328.

26. Kessler LA, Dugan P, Concannon JP. Systemic metastases of medulloblastoma promoted by shunting. Surg Neurol 1975;3:147-152.

27. Fiorillo A, Maggi G, Martone A, et al. Shunt-related abdominal metastases in an infant with medulloblastoma: long-term remission by systemic chemotherapy and surgery. J Neurooncol 2001;52:273-276.

28. Banna M, Lassman LP, Pearce GW. Radiological study of skeletal metastases from cerebellar medulloblastoma. Br J Radiol 1970;43:173-179.

29. Frankel A, Lau Q, Olson S. Lymph node metastasis of medulloblastoma in a young adult. Clin Neurosci 2009;16:1485-1486.

30. Sheikh B, Kanaan I. Lymph node metastasis in medulloblastoma. Pediatr 1994;20:269-271. 